\title{
Yield Interactions of Wheat Genotypes to Dates of Seeding in Eastern Mid Hills of Nepal
}

\author{
Rudra Bhattarai $^{* 1}$, Bedanand Chaudhary ${ }^{1}$, Dhruba Bahadur Thapa ${ }^{2}$, Ramesh Raj Puri ${ }^{6}$, Ram Nath Chaudhary ${ }^{5}$, Bibek Sapkota ${ }^{4}$, Kiran \\ Baral $^{3}$, Shukra Raj Shrestha ${ }^{1}$ and Surya Prasad Adhikari ${ }^{1}$ \\ ${ }^{1}$ Regional Agricultural Research Station, Tarahara, Nepal \\ ${ }^{2}$ Agricultural Botany Division, Khumaltar, Nepal \\ ${ }^{3}$ Hill Crop Research Program, Kabhre, Dolakha, Nepal \\ ${ }^{4}$ Nepal Agricultural Research Council, Singhadarbar, Plaza, Nepal \\ ${ }^{5}$ Agricultural Research Station, Pakhribas, Nepal \\ ${ }^{6}$ National Wheat Research Program, Bhairahawa,Nepal \\ *Corresponding author:bhattarairudra3@gmail.com
}

Received May 2015; Revised June 2015; Accepted July 2015

Scientific Editor: TB Gurung, BK Joshi

Copyright (C 2015 NARC. Permits unrestricted use, distribution, and reproduction in any medium, provided the original work is properly cited

\begin{abstract}
Wheat (Triticum aestivum L.) is one of the major cereal crops and staple food sources in Nepal. Wheat varieties being popular in mid hill regions are still in the early stages of adoption. Identification of appropriate date of seeding plays important role in enhancing the adoption rate ensuring the sustainable production. Therefore, three dates viz $15^{\text {th }}$ November, $1^{\text {st }}$ and $15^{\text {th }}$ December for seeding and twenty eight wheat genotypes were evaluated in a split plot design with two replications for two consecutive seasons in 2011/12 and 2012/13 at an altitude of 2200 masl of eastern Nepal. The results showed genetic differences and interaction effect of genotypes with the dates of sowing on grain yield, panicle length and effective tillers per square meter. The wheat sown on $1^{\text {st }}$ December showed the highest yield as compared to other sown dates. Similarly, WK1907, WK1911, WK1803, WK1915, WK1909, WK1714 and WK1803 produced highest yield among the tested genotypes with retaining maximum number of effective tillers and posed suitable maturity across all sowing date.
\end{abstract}

Key words: Genotypes, planting date, wheat, yield

\section{सारांश}

गहुँ नेपालको एक प्रमुख खाद्यान्न बाली हो। गहुँका नयाँ प्रचलित जातहरु कमै मात्रामा किसानको खेत बारीमा पुगेको पाईन्छ । सामान्यतया, गहुँ बालीको उत्पादकत्व स्थान र जातिय छनौट अनुसार पनि भरपर्ने हुन्छ। तसर्थ, उचित समय र स्थान अनुसारको उपयुक्त जातिय पहिचानको संयोजन बाट गहुँको बढी उत्पादन लिन सक्ने हुन सक्दछ। अभ नेपालका मध्य पहाड जस्ता भौगोलिक अवस्था रहेका स्थानहरुमा उचित समयको पहिचानका साथै गहुँको उपयुक्त जातको समन्वय उत्कफ्ट उत्पादन कालागी एक महत्वपुर्ण जानकारी हुनाका साथै सो बाट उत्पादनको दिगोपनाको सुनिश्चतता प्रदान गर्दछ। यी सबै जानकारी हासिल गर्ने उद्वेश्य अनुरुप $9 \%$ नोभेम्बर, 9 डिसेम्बर र $9 y$ डिसेम्बरको फरक मितिहरुमा २६ गहुँका जातहरु लाई स्पालिट प्लट डिजाईनमा तिन रेप्लिकेशन विधिद्वारा सन् २०१२ र २०१३ मा कृषि अनुसन्धान केन्द्र पाखीबासको २२०० मिटर समुद्र सतहमाथि अवस्थित प्लटहरुमा परीक्षण गरिएको थियो। दुई वर्ष सम्म संचालन भएको परीक्षणले गहुँको जातिय भिन्नता र बिभिन्न मितिमा छरिएको प्रभाव बालाको लम्बाई, नलहरुको संख्या र उत्पादनमा आधारित प्रक्षेपण गरि मल्यांकन गर्दा १ डिसेम्बरमा छरिएको गहुँका २६ जातहरु मध्येमा सबैभन्दा बढी उत्पादकत्व भएकाहरुमा WK1907, WK1911, WK1803, WK1915, WK1909, WK1714 र WK1803 रहेको र्निक्यौल गरियो ।

\section{INTRODUCTION}

Wheat is third most important major staple food crop in Nepal. The wheat crop supplements $20 \%$ of food calories contributing food to $36 \%$ of the global population. Productions of wheat crop in the country have reached approximately $1883147 \mathrm{mt}$ from 754474 ha of cultivated land with 2.496 t/ha yield (ABPSD 2013/2014). The national statistics shows that the average productivity of wheat in eastern hills was about 2.44 t/ha which is lesser as compared to other hilly regions and national yield (MoAC 2013). In general, wheat grain yield highly depends on water availability, high or low temperatures during the grain filling at maturity and other factors (GomezMacpherson and Richards 1995, Andarzian et al 2014) Thus, the identification of sowing date in relation to wheat genotype is an important management option to optimize grain yield potential (Ahmad and Fayyaz-ul-Hassan 2015).

Moreover, cold temperature related sterility is the major reason behind the yield loss where proper adjustment of planting date failed (Sthapit 1988). According to NWRP (2013), a delay of fifteen days from $21^{\text {st }}$ November might reduce the wheat production by 20 to $30 \%$, implying that, identification of the appropriate sowing date to plant wheat genotypes in specific agro-ecological conditions has high implication associated with sharp vertical gradients under mid hill condition of the country. Therefore, the present experiments, as we have aimed possess high importance to find out appropriate sowing dates in association with suitable genotypes in the mid-hill environment.

\section{MATERIALS AND METHODS}

Field experiments were laid out during the wheat production seasons in 2011 to 2013 at Agricultural Research Station, Pakhribas, Dhankuta, Nepal located at 2200 masl using split plot design with two replications. Three different seeding dates $\left(15^{\text {th }}\right.$ November, $1^{\text {st }}$ December and $15^{\text {th }}$ December) were used as main-plot and 28 genotypes were placed as sub plot factor. The genotypes comprised of wheat advanced lines from Khumal series, facultative wheat genotypes namely, $18^{\text {th }}$ FAWONN 222 and $18^{\text {th }}$ FAWONN 246 , whereas WK1204 was used as popular check variety common to the mid-hill condition of Nepal (NWRP 2013). All the genotypes were obtained from Agriculture Botany Division. 
The fertilizers were applied at the rate of 100: 60: $40 \mathrm{~kg} \mathrm{~N}: \mathrm{P}_{2} \mathrm{O}_{5}: \mathrm{K}_{2} \mathrm{O}$ (Nitrogen: Phosphorus: Potassium) ha ${ }^{-1}$ and the seed rate was 120 $\mathrm{kg} \mathrm{ha}^{-1}$. All other agronomic practices, e.g. method of planting, seeding rate, planting depth, weeding and harvesting were kept constant for all treatments. The experimental plot consisted of 6 rows of 2 meter long where continuous seeding was done manually. Ten plants from each plot were randomly selected to record the data for plant height and spike length. Similarly, yield was computed by weighing the weight of seeds per spike from four rows of each plot. The major measured traits were number of effective tillers per square meter, maturity days and yield. The number of effective tillers per square meter was calculated by counting tillers during the harvest from one square meter while maturity days were calculated by counting the days between dates of sowing and date to $95 \%$ physiological maturity. The plants were harvested and measured separately from different sown date and traits; and computed using M-STAT Software. From the used parameters, mean, coefficient of variation (CV), least significant difference of mean and probability value were calculated.

\section{RESULTS}

The levels of significance for different factors and their interactions for various measured traits were presented in Table 2. The analysis of variance showed that the mean squares for genotypes in all dates of sowing were significantly $(\mathrm{P}<0.05)$ different for yield $(\mathrm{t} / \mathrm{ha})$, number of tillers per square meter and maturity days indicating the existence of genetic variability (Table 2).

Moreover, number of tillers per square meter and yield $(\mathrm{t} / \mathrm{ha})$ were significantly $(\mathrm{P}<0.05)$ different at $1 \%$ level of significance among genotypes over the years. The general trend showed that 10 to 12 average day's diminution for number of days to $95 \%$ maturity with every week delayed in planting time (Table 2).

The wheat sown on $1^{\text {st }}$ December yielded 308 tillers per square meter which was the highest among all, followed by sown on $15^{\text {th }}$ November with 295 tillers per square meter. The wheat seeded on $15^{\text {th }}$ December produced the lowest 274 tillers and minimum yield of grain 5.54 t/ha (Table 2), while seeded on $1^{\text {st }}$ December yielded the highest $6.82 \mathrm{t} /$ ha grain. Similarly, crop sown on the first date $\left(15^{\text {th }}\right.$ November) took the highest number of days for maturation, comparing to the wheat sown on other second and third dates.

In comparison among the genotypes, WK1914 produced 394 tillers per square meter followed by WK1902 with 388 tillers per square meter. In addition to this, genotypes WK1905, WK1915, $18^{\text {th }}$ FAWWON222, WK1713, WK1906, WK1901 and WK1907 produced more number of effective tillers per square meter with additional advantage of medium maturity days (Table 2). Among the genotypes, WK1723 was earliest in maturity (161 days) (Table 2). Genotypes WK1714, WK 1902, WK 1803 and WK 1723 produced higher grain yield among all sowing dates with 8.07, 7.66, 7.42 and $7.36 \mathrm{t} / \mathrm{ha}^{-1}$, respectively. Besides them, genotypes WK1907, WK1911, WK1915, WK1909 and WK1712 gave stable yield in all seeding dates.

\section{DISCUSSION}

The result showed that the wheat genotypes sown on $1^{\text {st }}$ December had highest yield with highest number of mean tillers per square meter than wheat sown in other dates, in general (Table 2). Our findings showed that wheat sowing can be recommended on around $1^{\text {st }}$ December in high hill localities similar to that of the present experimental site. Similar to the present finding Subedi et al (1985) showed that wheat seeded on $6^{\text {th }}$ December gave maximum yield in mid hill conditions of Nepal. The cumulatively results might imply with increasing altitude probably the wheat should be sown little earlier than approximately in late November, The early ( $15^{\text {th }}$ November) and delayed $\left(15^{\text {th }}\right.$ December) seeded wheat in present experiments could not exceed the yield of the $1^{\text {st }}$ December. This could be due to yield loss associated with delayed or early sowing inappropriate for the specific mid hill location environmental interaction with the genotypes used. Since the yield is associated with the number of tillers, it has been found that number of tillers per unit area could be affected substantially in early or delayed seeding (Sharma and Garg 2002).

In general, similar results has been obtained elsewhere in late planted wheat because of the problem of field drought that hamper the production of tillers; and thus to the yield (Mohammad et al 2003). The delayed sown wheat produced low number of effective tillers per square meter probably due to drought and rise in temperature, as the plant faces increasingly warm temperature especially towards the maturation period, when plant start to enrich the grains. In present experiment the low number of tillers and yield in delayed sown wheat might be due to warming air temperature at the end of February, when day length inclined to be lengthen supporting rise in air temperature.

The genotypes WK1905, WK1914, WK1902, WK1915, 18TH FAWWON222, WK1713 WK1906, WK1901, WK1714, WK1803 and WK1907 had produced more number of effective tillers $\mathrm{m}^{-2}$ (Table 2). The tiller numbers contributes in one or another way to grain yield (Bassu et al 2010). The higher number of tiller bearing trait could be one of the important characteristics for wheat improvement (Subedi et al 1985), because higher number of tillers favored more adaptation and production comparing to low tiller bearing genotypes. Therefore, tillers per square meter would be the most appropriate traits to be utilized for the wheat improvement.

Among genotypes, WK1714 and WK1803 matured in 145 and 162 days, with mean yield of 8.07 (ton/ha) and 7.42 (ton/ha), respectively (Table 2). The wheat sown on $15^{\text {th }}$ November took higher number of days to mature than comparing to seeded in other dates. This is mainly because of cool temperatures persisted, which resulted in slow seedling emergence and slow subsequent development and fruiting. Similar observation has been mentioned by Subedi et al (1985) that low temperature resulted in slow vegetative and reproductive growth in plants. Since the air temperature is closely associated with the altitude, facing of crop fields to various directions, therefore care should be taken to imply the results of present experiments to be generalized elsewhere. More studies on wheat genotypes yield attribute at various altitudinal gradients in mid hill and southern terai might be of interest for rapid adoption of the wheat farming in applicable localities.

It has been calculated that mean number of days for maturation might be reduce by 12 days comparing to those sown on $15^{\text {th }}$ November and $1^{\text {st }}$ December. An enforced maturity has been noticed to the wheat sown on $15^{\text {th }}$ December (Table 2). Similar observation has also been reported by Sandhu (1993), where duration of reproductive phase such as flowering and maturity were decreased with delaying in 
seeding dates. The low yield in wheat sown on $15^{\text {th }}$ November justified that specific timing would be slightly earlier for genotypes used for the specific mid hill localities because of persisting low temperature faced by wheat genotypes around December, January and February which do not stimulate positive attributes for yield performance in the specified locality.

The wheat sown on $1^{\text {st }}$ December were matured in moderate duration comparing to delayed or forced maturity caused either by early or late sowing. This timing of seeding probably perfectly coincided with the yield attributes of genotypes used in specified mid hill localities. Moreover, this timing also perfectly coincided and fit to rice-wheat cropping system in mid hills of Nepal. Therefore, this timing should be recommended for the best yield performance of used genotypes (Table 2) in specific mid hill localities.

Genotypes WK1907, WK1911, WK1915, WK1909, WK1714 and WK1803 produced the highest yield along with at par yield to check variety, WK1204. maturing in medium duration and yielding highest tillers across the planting dates. Therefore, it is likely, these genotypes could be promoted as varieties under eastern mid hill condition of Nepal. Besides that, WK1907, WK1911, WK1915, WK1909, WK1714 and WK1803 were more stable genotypes, which could be utilized under advanced yield and subsequent promotional trials. In addition, based on present findings it is recommendable that the wheat genotypes preferably should be seeded in the first week of December for increased grain production in the eastern hills environments of Nepal.

Table 2. Interaction of wheat genotypes with different dates of sowing and their combined mean for grain yield (t/ha), number of tillers per square meter and maturity days during 2011/2012 and 2012/2013

\begin{tabular}{|c|c|c|c|c|c|c|c|c|c|c|c|c|}
\hline \multirow[t]{2}{*}{ Genotypes } & \multicolumn{4}{|c|}{ Yield (t/ha) } & \multicolumn{4}{|c|}{ Tillers/square meter } & \multicolumn{4}{|c|}{ Maturity days } \\
\hline & $15 \mathrm{Nov}$ & $1 \mathrm{Dec}$ & 15 Dec & Mean & 15 Nov & 1 Dec & 15 Dec & Mean & 15 Nov & $1 \mathrm{Dec}$ & 15 Dec & Mean \\
\hline F-7@-45 & 6.97 & 8.22 & 6.02 & 7.07 & 317 & 255 & 268 & 280 & 176 & 166 & 152 & 165 \\
\hline WK1712 & 7.25 & 7.11 & 5.13 & 6.50 & 248 & 254 & 235 & 246 & 177 & 165 & 153 & 165 \\
\hline WK1713 & 7.68 & 7.60 & 5.30 & 6.86 & 316 & 335 & 294 & 315 & 186 & 166 & 149 & 167 \\
\hline WK1910 & 7.10 & 8.43 & 5.63 & 7.05 & 239 & 246 & 206 & 230 & 182 & 166 & 169 & 172 \\
\hline WK1906 & 3.07 & 4.56 & 2.30 & 3.31 & 299 & 343 & 291 & 311 & 194 & 185 & 168 & 182 \\
\hline $18^{\text {th }}$ FAWWON 222 & 5.69 & 6.10 & 5.27 & 5.69 & 414 & 379 & 300 & 364 & 192 & 180 & 169 & 180 \\
\hline WK1907 & 4.77 & 5.88 & 5.82 & 5.49 & 283 & 342 & 240 & 288 & 199 & 183 & 168 & 183 \\
\hline WK1905 & 5.74 & 5.10 & 5.08 & 5.31 & 424 & 446 & 411 & 427 & 186 & 181 & 159 & 175 \\
\hline WK1976 & 6.54 & 5.75 & 5.03 & 5.77 & 272 & 254 & 245 & 257 & 188 & 172 & 149 & 170 \\
\hline WK1723 & 7.78 & 7.96 & 6.35 & 7.36 & 222 & 288 & 249 & 253 & 168 & 164 & 152 & 161 \\
\hline WK1901 & 7.66 & 6.39 & 5.96 & 6.67 & 342 & 290 & 282 & 305 & 184 & 168 & 153 & 168 \\
\hline WK1909 & 6.39 & 6.78 & 6.15 & 6.44 & 256 & 259 & 207 & 241 & 182 & 167 & 156 & 168 \\
\hline $\mathrm{F}(5)-1-\mathrm{I}-3$ & 6.25 & 6.08 & 6.10 & 6.14 & 204 & 256 & 262 & 241 & 182 & 167 & 144 & 164 \\
\hline WK1714 & 10.1 & 8.13 & 5.98 & 8.07 & 307 & 217 & 205 & 243 & 173 & 169 & 169 & 170 \\
\hline WK1904 & 7.48 & 6.75 & 4.92 & 6.38 & 300 & 298 & 303 & 300 & 189 & 180 & 145 & 171 \\
\hline WK1792 & 5.16 & 4.92 & 4.97 & 5.02 & 282 & 312 & 275 & 290 & 172 & 163 & 153 & 163 \\
\hline WK1804 & 7.64 & 7.62 & 6.70 & 7.32 & 289 & 324 & 234 & 282 & 175 & 172 & 155 & 167 \\
\hline WK1204 & 8.59 & 8.63 & 6.41 & 7.88 & 268 & 270 & 247 & 262 & 182 & 167 & 156 & 168 \\
\hline WK1030 & 4.67 & 5.99 & 5.98 & 5.55 & 276 & 291 & 278 & 282 & 186 & 172 & 158 & 172 \\
\hline WK1902 & 8.84 & 7.96 & 6.17 & 7.66 & 390 & 438 & 336 & 388 & 175 & 174 & 156 & 168 \\
\hline WK1914 & 5.16 & 6.30 & 5.35 & 5.60 & 396 & 438 & 348 & 394 & 196 & 179 & 168 & 181 \\
\hline WK1710 & 6.20 & 7.01 & 5.71 & 6.31 & 252 & 276 & 236 & 255 & 182 & 163 & 150 & 165 \\
\hline $18^{\text {th }}$ FAWWON 246 & 6.25 & 7.16 & 4.49 & 5.97 & 282 & 268 & 228 & 259 & 185 & 169 & 160 & 171 \\
\hline WK1915 & 7.26 & 7.10 & 4.81 & 6.39 & 336 & 402 & 370 & 369 & 182 & 167 & 163 & 171 \\
\hline WK1901 & 7.06 & 6.65 & 6.81 & 6.84 & 185 & 260 & 249 & 231 & 182 & 167 & 154 & 168 \\
\hline WK1803 & 8.28 & 7.96 & 6.01 & 7.42 & 271 & 312 & 363 & 315 & 182 & 168 & 153 & 168 \\
\hline WK1481 & 5.71 & 6.17 & 5.93 & 5.94 & 258 & 256 & 250 & 255 & 180 & 167 & 153 & 167 \\
\hline WK1713 & 7.65 & 6.60 & 4.77 & 6.34 & 331 & 303 & 259 & 298 & 182 & 167 & 154 & 168 \\
\hline $\mathrm{CV}, \%$ & \multicolumn{3}{|c|}{17} & 21.9 & \multicolumn{3}{|c|}{15.2} & 22.3 & \multicolumn{3}{|c|}{2.1} & 2.9 \\
\hline LSD (0.05) & \multicolumn{3}{|c|}{1.67} & 3.2 & \multicolumn{3}{|c|}{71.58} & 126.5 & \multicolumn{3}{|c|}{7.26} & 9.913 \\
\hline & \multicolumn{3}{|c|}{$<0.001$} & 0.14 & \multicolumn{3}{|c|}{$<0.001$} & 0.85 & \multicolumn{3}{|c|}{0.031} & 0.39 \\
\hline
\end{tabular}

\section{ACKNOWLEDGEMENTS}

Authors would like to express their gratitude to Nepal Agricultural Research Council for providing fund for the study. ARS, Pakhribas, Dhankuta and RARS Tarahara, Sunsari teams are highly acknowledged for their support and cooperation.

\section{REFERENCES}

ABPSD. 2013/2014. Statistical information on Nepalese Agriculture. Ministry of Agriculture Development, Nepal. Food crops in Nepal. 39:231-235.

Ahmed M and F Hassan. 2015. Response of Spring Wheat (Triticum aestivum L.) Quality Traits and Yield to Sowing Date, PLoS One v.10(4); PMC4415767, e0126097.

Bassu S, F Giunta and R Motzo. 2010. Effects of sowing date and cultivar on spike weight and kernel number in durum wheat. Crop Pasture Sci. 61:287-295. doi:10.1071/CP09235.

Gomez-Macpherson H and Richards RA. 1995. Effect of sowing time on yield and agronomic characteristics of wheat in south-eastern Australia Aust. J. Agric. Res., 46:1381-1399.

NWRP. 2013. Rice-wheat system: Opportunities and constraints. In: Annual report-2013 National Wheat Research Program (NWRP) Nepal Agricultural Research Council, Bhairahawa - Rupandehi - Nepal. Pp.60-65. 
MoAD. 2013. Statistical information on agriculture in Nepal, GoN, MoAD, Agri-Business Promotion and Statistics Division Statistics Section, Singha Durbar, Kathmandu Nepal.

Sandhu IS, Sharma AR, and Sur H S.1999. Yield Performance and Heat Unit Requirement of Wheat (Triticum aestivum L) Varieties as Affected by Sowing Dates under Rainfed Conditions. Indian Journal of Agricultural Science. 69(3):175-179.

Sharma AK and DK Garg. 2002. Genetic variability in wheat (Triticum aestivum L.) crosses under different normal and saline environments. Annals Agric. Res. 23(3):497-499.

Sthapit BR. 1988. Studies on wheat sterility problem in the hills, tar and Terai of Nepal, LARC Technical Paper No. 16/88. Pokhara (Nepal): Lumle Agricultural Research Centre.

Subedi KD, Joshi KD, Sthapit BR, TP Tiwari.1985. Studies on causes of wheat sterility problem in the hills, tar and terai of Nepal. LRARC, Nepal.

Mohammed SC, L Ali and M Akhtar. 2003. Wheat Following the Cotton and Rice Based Cropping System in Pakistan. Agron. Research Station. Bahawapur, Pakistan. Pp.112-113. 